\title{
Model rehabilitacji audiologicznej po wszczepieniu implantu ślimakowego opracowany na podstawie Międzynarodowej Klasyfikacji Funkcjonowania, Niepełnosprawności i Zdrowia (ICF)
}

\section{The model of audiological rehabilitation developed on the basic of the International Classification of Functioning, Disability and Health (ICF)}

\author{
Artur Lorens \\ Instytut Fizjologii i Patologii Słuchu, Światowe Centrum Słuchu, Zakład Implantów i Percepcji Słuchowej, \\ Warszawa/Kajetany
}

Adres autora: Artur Lorens, Światowe Centrum Słuchu, Zakład Implantów i Percepcji Słuchowej, ul. Mokra 17, Kajetany, 05-830 Nadarzyn, e-mail: a.lorens@ifps.org.pl

\section{Streszczenie}

Celem interwencji medycznej polegającej na zastosowaniu implantu ślimakowego w przypadku głębokiego i znacznego niedosłuchu jest poprawa funkcjonowania pacjentów. Funkcjonowanie, jako dziedzina zdrowia, obejmuje wszystkie funkcje ciała ludzkiego, aktywności jednostki i uczestniczenie człowieka w różnych sytuacjach życiowych. W pracy omówiono możliwość wykorzystania Międzynarodowej Klasyfikacji Funkcjonowania, Niepełnosprawności i Zdrowia (ang. International Classification of Functioning, Disability and Health, ICF), jako narzędzia klinicznego, do planowania, realizacji i oceny wyników rehabilitacji audiologicznej po wszczepieniu implantu ślimakowego. Rehabilitacja audiologiczna oparta na ICF definiowana jest holistycznie jako wielodyscyplinarne i kompleksowe postępowanie, mające na celu ograniczenie wywołanych niedosłuchem deficytów w funkcjach struktur ciała ludzkiego, aktywności i uczestnictwie. Dokonano próby ujednolicenia, za pomocą ICF-u, języka stosowanego w opisie opieki zdrowotnej po wszczepieniu implantu ślimakowego, w celu usprawnienia porozumiewania się różnych specjalistów i pracowników służby zdrowia: lekarzy, logopedów, psychologów, pedagogów, inżynierów i pracowników naukowych.

Słowa kluczowe: implant ślimakowy • niedosłuch • rehabilitacja audiologiczna • niepełnosprawność • ICF

\begin{abstract}
Cochlear implantation, as a medical intervention, is aiming for better functioning of hearing impaired individuals rather than curing the illness. The term functioning refers to all body functions, activities and participation. In the paper, the International Classification of Functioning, Disability and Health, known more commonly as ICF, was used as a clinical tool for planning and evaluation of audiological rehabilitation after cochlear implantation. Audiological rehabilitation is here defined holistically as the reduction of hearing-loss-induced deficits of the function, activity and participation. The attempt was made to develop a common language, used by physicians, speech therapists, psychologists, pedagogues, clinical engineers and hearing scientists, in the description of health care provision after cochlear implantation.
\end{abstract}

Key words: cochlear implant $\bullet$ hearing loss • audiological rehabilitation $\bullet$ impairment $\bullet$ ICF

Wprowadzenie

Słuch odgrywa istotną rolę w życiu człowieka, pełniąc funkcję biologiczną (funkcja sensoryczna) oraz funkcję ciała (słyszenie) [1]. Zadaniem komórek słuchowych ucha wewnętrznego jest transformacja energii akustycznej w impulsy neuronalne, co jest niezbędne do tego, aby powstawało wrażenie słuchowe (funkcja biologiczna). Uszkodzenie tych komórek stanowi odchylenie od normy biologicznej, zaburza funkcję ucha wewnętrznego i tym samym jest stanem patologicznym zwanym niedosłuchem zmysłowo-nerwowym [2]. W zależności od rozległości i rodzaju 
uszkodzenia niedosłuch może mieć różny stopień nasilenia, prowadząc do ograniczeń w słyszeniu (funkcja ciała). W większości przypadków uszkodzenie komórek słuchowych jest procesem nieodwracalnym [2]. Zgodnie z medycznym modelem niepełnosprawności, niedosłuch zmysłowo-nerwowy jako deficyt funkcjonalny ucha wewnętrznego (części układu sensorycznego) prowadzi do wystąpienia niepełnosprawności sensorycznej (niesprawności - ang. impairment). W modelu medycznym niepełnosprawność postrzegana jest podobnie jak choroba przez pryzmat stanu patologicznego wymagającego adekwatnego leczenia [3]. W przypadku braku skutecznych metod leczniczych zalecane są odpowiednie działania rehabilitacyjne w celu kompensacji deficytu funkcjonalnego (wady) spowodowanego stanem patologicznym [4].

Z uwagi na brak możliwości regeneracji komórek słuchowych, a tym samym brak możliwości skutecznego leczenia niepełnosprawności słuchowej (niesprawności), jedyną możliwą do zastosowania formą interwencji medycznej jest rehabilitacja medyczna $z$ zastosowaniem medycznego środka technicznego (protezy słuchowej). Do protez słuchowych stosowanych w rehabilitacji medycznej osób $\mathrm{z}$ niedosłuchem zmysłowo-nerwowym należą aparaty słuchowe i implanty ślimakowe [2]. Aparaty słuchowe stosowane są przede wszystkim w przypadkach niedosłuchu stopnia lekkiego do znacznego, natomiast $\mathrm{w}$ przypadku głębokiego uszkodzenia słuchu oraz w przypadku całkowitej i częściowej głuchoty wszczepiane są implanty ślimakowe $[5,6]^{1}$. Zadaniem implantów ślimakowych jest odtworzenie procesu transformacji dźwięku w impulsy neuronalne poprzez zastąpienie niesprawnych komórek słuchowych elektryczną stymulacją przetrwałych włókien nerwowych [2]. System implantu ślimakowego złożony jest z części wewnętrznej - implantu, składającego się z odbiornika i stymulatora elektrycznego we wspólnej obudowie wraz z wiązką elektrod oraz z części zewnętrznej - cyfrowego, wielokanałowego procesora mowy [7]. Procesor mowy jest urządzeniem cyfrowym, zatem dobór parametrów elektrostymulacji polega na odpowiednim jego zaprogramowaniu. Korzystając z komputera PC oraz specjalistycznego oprogramowania i interfejsu, wpisuje się parametry stymulacji elektrycznej do wewnętrznej pamięci procesora mowy. Zbiór parametrów, do których należą: poziomy prądów odpowiadające progowi słyszenia oraz wrażeniu komfortowego słyszenia, liczba aktywnych elektrod, prędkość stymulacji, wybór strategii kodowania, kształt funkcji kompresji, określany jest jako mapa pacjenta [7]. Interwencja medyczna $\mathrm{z}$ zastosowaniem implantów ślimakowych polega na operacyjnym wszczepieniu części wewnętrznej: kapsuła implantu jest umieszczana w niszy w kości skroniowej i przykrywana płatem skórnym, a wiązka elektrod wprowadzana jest do ucha wewnętrznego (ślimaka) oraz na postępowaniu pooperacyjnym mającym służyć kompensacji utraconej funkcji ciała - słyszenia z wykorzystaniem wszczepionego implantu [7]. A zatem w wyniku interwencji chirurgicznej oraz innych działań wchodzących w zakres szeroko pojętej rehabilitacji medycznej prowadzonej $\mathrm{z}$ wykorzystaniem implantu ślimakowego możliwa jest kompensacja wady słuchu i przeciwdziałanie negatywnym konsekwencjom niepełnosprawności (niesprawności) słuchowej.

\section{Model funkcjonalny niepełnosprawności}

Rozwój technologiczny, który dokonuje się w ostatnich latach, w coraz większym stopniu wpływa na życie osób niepełnosprawnych. Prowadzi to do gwałtownego rozwoju nauki o rehabilitacji, która ma swoje korzenie w medycznym modelu niepełnosprawności. Według amerykańskiego Instytutu Medycyny rehabilitacja, w połączeniu z inżynierią biomedyczną, powinna wykorzystywać najnowsze osiągnięcia nauk medycznych, społecznych i technicznych dotyczących możliwości przywracania utraconych funkcji biologicznych i funkcji ciała jak również możliwości udoskonalania jakości i poszerzania interakcji między człowiekiem a jego otoczeniem. [8]

Podstawowym modelem niepełnosprawności zaczerpniętym $\mathrm{z}$ socjologii, do którego odwołuje się obecnie nauka o rehabilitacji, jest model funkcjonalny [9]. Utratę sprawności słuchowej zgodnie z tym modelem można przedstawić jako dynamiczny proces złożony z czterech podprocesów, pomiędzy którymi występują interakcje (sprzężenia zwrotne). Do podprocesów tych zalicza się: 1) proces patologiczny zachodzący na poziomie molekularnym w obrębie komórek słuchowych, 2) uszkodzenie objawiające się deficytem sensorycznym, 3) ograniczenie funkcjonalne (niezdolność do wykonania konkretnego zadania, np. zrozumienia przekazu ustnego), 4) trudności napotykane w świecie społecznym, tj. trudności w spełnianiu wymagań społecznych $[8,9]$.

\section{Międzynarodowa Klasyfikacja Funkcjonowania, Niepełnosprawności i Zdrowia (ICF)}

Zgodnie z najnowszymi zaleceniami organizacji audiologicznych opieka pooperacyjna po wszczepieniu implantu ślimakowego powinna być oparta na najnowszym modelu funkcjonalnym niepełnosprawności, który został stworzony na potrzeby Międzynarodowej Klasyfikacji Zdrowia, Funkcjonowania i Niepełnosprawności (ang. International Clasification of Functioning Disability and Health, ICF) [10,11]. Model ten zakłada, że niepełnosprawność jest to termin całościowy, obejmujący uszkodzenia (ang. impairment), ograniczenia aktywności (ang. limitations in activation) oraz ograniczenia uczestnictwa (ang. restrictions in participation) [12] $]^{2}$. Uszkodzenie jest problemem w funkcjonowaniu bądź strukturze ciała; ograniczenia aktywności odnoszą się do trudności napotykanych przez jednostki w wykonywaniu działań bądź zadań; podczas gdy ograniczenie uczestnictwa jest problemem doświadczanym przez jednostkę w zaangażowaniu w sytuacje życiowe [1]. Ponadto ICF określa ludzkie funkcjonowanie

\footnotetext{
${ }^{1}$ zob. A. Piotrowska i wsp. Implanty ślimakowe - wczoraj i dziś, H. Skarżyński i wsp. Zachowanie czułości słuchu dla niskich częstotliwości po wszczepieniu implantu ślimakowego oraz H. Skarżyński i wsp. Nowa strategia leczenia częściowej głuchoty w tym numerze „Nowej Audiofonologii”.

2. Jest to rewizja modelu zawartego w poprzednio obowiązującej klasyfikacji ICIDH (ang. International Classification of Impairments, Disabilities and Handicaps) WHO z 1980 r., w której niepełnosprawność była rozpatrywana w następujących kategoriach:

- Upośledzenie lub uszkodzenie (ang. impairment) - oznacza wszelki brak lub anormalność anatomicznej struktury narządów oraz brak lub zaburzenia funkcji psychicznych lub fizycznych organizmu.
} 


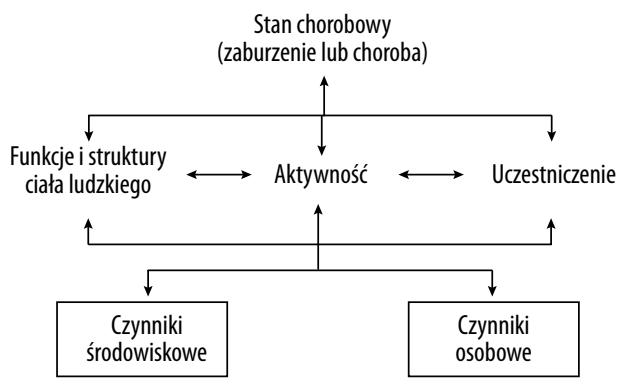

Rycina 1. Zależności między składnikami ICF [1]

Figure 1. Correlation between ICF components [1]

i jego ograniczenia jako rezultat dynamicznej interakcji pomiędzy stanem(ami) zdrowia a czynnikami kontekstualnymi. Ograniczenia sprawności są ujmowane jako interakcja między jednostką a jej stanem(ami) zdrowia oraz otoczeniem (czynniki kontekstowe) [1]. Zależności między składnikami ICF ilustruje rycina 1.

A zatem w modelu, do którego odwołuje się ICF, wyróżnia się pięć obszarów [1]:

1) Funkcje i struktury ciała - fizjologiczne funkcje systemów ciała oraz anatomiczne czesści ciała, takie jak: tkanki, organy, układy i systemy. Wszelkie (patologiczne) zmiany na tym poziomie nazywane są uszkodzeniami/ upośledzeniami.

2) Aktywność - wykonanie czynności/zadań/przedsięwzięć lub podejmowanie jakiejś akcji przez jednostkę. Ograniczenia aktywności sa to trudności, jakie dana osoba może mieć w podejmowaniu działań.

3) Uczestniczenie - zaangażowanie w sytuację życiową. Ograniczenia uczestniczenia są to problemy utrudniające danej osobie angażowanie się w sytuacje życiowe.

4) Czynniki kontekstowe środowiskowe (zewnętrzne) tworzą fizyczne i społeczne środowisko oraz system postaw, w którym żyją ludzie (np. klimat, warunki zamieszkania, prawodawstwo oraz postawa innych ludzi).

5) Czynniki kontekstowe osobowe (wewnętrzne) - szczególne cechy charakteryzujące daną osobę, które mogą odegrać rolę w niepełnosprawności na dowolnym poziomie; należą do nich cechy, które nie są elementem stanu zdrowia (płeć, rasa, wiek, inne warunki zdrowotne, sprawność fizyczna, styl życia, nawyki, wychowanie, sposoby radzenia sobie $z$ trudnościami, środowisko społeczne, wykształcenie, zawód, przeszłe i obecne doświadczenia, ogólne wzorce zachowań, style charakteru, cechy psychologiczne).

ICF zawiera listy poszczególnych funkcji i struktur ciała, nazw czynności i form uczestnictwa jak również listę czynników zewnętrznych (środowiskowych) wywierających wpływ na każdy $\mathrm{z}$ elementów funkcjonowania i niepełnosprawności. „Czynniki osobowe” są drugim składnikiem, który obejmują czynniki kontekstowe. Nie zostały one sklasyfikowane w ICF ze względu na związane z nimi duże zróżnicowanie społeczne i kulturowe. Klasyfikacja ICF dostarcza opisu sytuacji dotyczących funkcjonowania człowieka i jego ograniczeń oraz służy jako narzędzie do organizacji tych informacji [13]. Tworzy strukturę porządkującą informacje w logicznie powiązany i łatwo dostępny sposób [14].

\section{Listy kluczowe ICF dla niedosłuchu}

ICF jest wielozadaniową klasyfikacją opracowaną na użytek wielu dyscyplin i różnych sektorów, zwłaszcza związanych z opieką zdrowotną [1]. Klasyfikacja ta wykorzystywana jest obecnie coraz częściej, jako narzędzie kliniczne, do oceny potrzeb zdrowotnych, doboru metod postępowania w określonych stanach chorobowych, oceny profesjonalizmu oraz oceny rehabilitacji i jej wyników [15]. Poziom złożoności klasyfikacji (zawiera 1424 kategorie oceny) sprawia, że pojawiają się trudności w aplikowaniu jej do ogólnej praktyki medycznej [16-18]. Aby umożliwić zastosowanie ICF w opiece nad osobami z niedosłuchem, zostały podjęte prace naukowo-badawcze, których rezultatem było opracowanie tzw. list kluczowych, czyli list poszczególnych funkcji i struktur ciała, form czynności i uczestnictwa, jak również listy czynników zewnętrznych związanych $\mathrm{z}$ niepełnosprawnością słuchową [19-21]. Listy kluczowe dla niedosłuchu (ang. core sets for hearing loss) umieszczone zostały w tabeli 1, a zawarte w nich treści pochodzą z polskiej wersji językowej Klasyfikacji ICF [1]. W niniejszym artykule listy te zostały wykorzystane do opisu rehabilitacji audiologicznej prowadzonej w Instytucie Fizjologii i Patologii Słuchu u pacjenta po wszczepieniu implantu ślimakowego. Termin „rehabilitacja audiologiczna” rozumiany jest tu zgodnie $\mathrm{z}$ definicją zaproponowaną przez Stephens i Hétu i rozwijaną przez Chisolma oraz Sweetowa i Palmera [22-24]. Zgodnie $\mathrm{z}$ nią rehabilitacja audiologiczna to postępowanie ukierunkowane na rozwiązanie problemu (ang. a problem-solving excercise), mające na celu ograniczenie negatywnych skutków niedosłuchu poprzez stworzenie warunków do aktywności i przywrócenie pełnego uczestniczenia w sytuacjach życiowych. Według cytowanych powyżej autorów niekwestionowaną podstawa interwencji audiologicznej jest zastosowanie odpowiedniej protezy słuchu w celu kompensacji funkcji słuchowych utraconych na skutek niedosłuchu [22-24]. W rehabilitacji audiologicznej muszą być jednak wykorzystane również inne strategie pomocowe ukierunkowane na przeciwdziałanie ograniczeniom w aktywności i uczestnictwie, takie jak: treningi percepcyjne, wsparcie i edukacja $[25,26]$. Takie rozumienie rehabilitacji audiologicznej wydaje się najbardziej zbieżne $\mathrm{z}$ funkcjonalnym modelem niepełnosprawności opracowanym na potrzeby ICF. W artykule opisano model rehabilitacji audiologicznej użytkowników implantów ślimakowych oparty na klasyfikacji ICF. Ponadto przedstawiono przykładowe aplikacje kliniczne wybranych technik i metod rehabilitacyjnych wykorzystywanych w praktyce klinicznej w Zakładzie Implantów i Percepcji Słuchowej Instytutu Fizjologii i Patologii Słuchu. W dalszej części artykułu termin 'niepełnosprawność słuchowa'

\footnotetext{
- Niepełnosprawność funkcjonalna (ang. disability) - oznacza wszelkie ograniczenie lub brak wynikające z uszkodzenia zdolności wykonywania czynności w sposób i zakresie uważanym za normalny dla człowieka.

- Upośledzenie lub niepełnosprawność społeczna (ang. handicap) - oznacza mniej uprzywilejowaną lub mniej korzystną sytuację danej osoby, wynikającą z uszkodzenia i niepełnosprawności funkcjonalnej, która ogranicza lub uniemożliwia jej wykonywanie ról związanych z jej wiekiem, płcią oraz sytuacją społeczną i kulturową.
} 
Tabela 1. Listy kluczowe ICF dla niedosłuchu [1]

Table 1. ICF core sets for hearing loss [1]

\section{FUNKCJE CIAŁA LUDZKIEGO}

= Funkcje ciała ludzkiego (z włączeniem funkcji psychicznych) są to procesy fizjologiczne poszczególnych układów ciała.

b126 Funkcje temperamentu i osobowości

Ogólne funkcje psychiczne związane z konstytucjonalną dyspozycją danej osoby do reagowania na sytuacje w określony sposób, w tym zespót cech psychicznych, odróżniających daną osobę od innych.

Obejmuje: funkcje ekstrawersji, introwersji, zgodności, sumienności, stabilności psychicznej i emocjonalnej i otwartości na doświadczenia, optymizm, wyszukiwanie nowości, pewność, wiarygodność

Nie obejmuje: funkcje intelektualne (b117); funkcje energii i napędu (b130); funkcje psychomotoryczne (b147); funkcje emocjonalne (b152)

b140 Funkcje uwagi

Swoiste funkcje psychiczne umożliwiające skupienie się przez niezbędny odstęp czasu na bodźcu zewnętrznym lub przeżyciach wewnętrznych.

Obejmuje: funkcje trwałości, przerzutności, zmiennej podzielności i dzielenia uwagi, koncentracja, rozpraszalność Nie obejmuje: funkcje świadomości (b110); funkcje energii i napędu (b130); funkcje snu (b134); funkcje pamięci (b144); funkcje psychomotoryczne (b147); funkcje percepcyjne (b156)
b144
Funkcje pamięci

Swoiste funkcje psychiczne umożliwiające rejestrowanie i przechowywanie informacji oraz - w razie potrzeby - odtwarzanie jej. Obejmuje: funkcje związane z pamięcia krótkotrwałą i długotrwała, natychmiastowa, świeżą i odległa; rozpiętość pamięci; odtwarzanie pamięci, przypominanie; funkcje wykorzystywane $w$ trakcie przywotywania z pamięci i uczenia się jak w niepamięci nominalnej, wybiórczej i dysocjacyjnej

Nie obejmuje: funkcje świadomości (b110); funkcje orientacji (b114); funkcje intelektualne (b117); funkcje uwagi (b140); funkcje percepcyjne (b156); funkcje myślenia (b160); wyższe funkcje poznawcze (b164); funkcje językowe (b167); funkcje liczenia (b172)
b152
Funkcje emocjonalne

Swoiste funkcje psychiczne odnoszące się do uczuć i afektywnych składników procesów umysłu.

Obejmuje: funkcje związane z dostosowaniem emocji, regulacją i rozpiętością emocji; afekt, smutek, szczęście, miłość, strach, gniew, nienawiść, napięcie, lęk, radość, żal, chwiejność emocjonalna; spłycenie afektu Nie obejmuje: funkcje temperamentu i osobowości (b126); funkcje energii i napędu (b130)
b210
Funkcje widzenia

Funkcje zmysłowe odnoszące się do odbierania obecności światła oraz wrażenia formy, wielkości, kształtu i koloru bodźca wzrokowego.

Obejmuje: funkcje odbierania światła i koloru, ostrość widzenia odległego i bliskiego obrazu, widzenie jednooczne i widzenie obuoczne, pole widzenia, jakość widzenia, jakość obrazu wzrokowego, upośledzenia jak krótkowzroczność, nadwzroczność, astygmatyzm, niedowidzenie połowicze, ślepotę barw (daltonizm), widzenie tunelowe, mroczek środkowy i obwodowy, widzenie podwójne, ślepotę zmierzchowa, zaburzona zdolność przystosowania się do światta Nie obejmuje: funkcje percepcyjne (b156)

b230 Funkcje styszenia

Funkcje zmysłów dotyczące odbierania obecności dźwięków, rozróżniania lokalizacji, wysokości tonu, głośności i jakości dźwięków.

Obejmuje: funkcje styszenia, rozróżnianie dźwięków, umiejscowienie źródła dźwięku, lateralizację dźwięku, rozróżnianie mowy, gtuchotę, upośledzenie słuchu, utratę stuchu Nie obejmuje: funkcje percepcyjne (b156); funkcje językowe (b167)

Uczucie zaburzonej równowagi, upadania, szumów usznych, zawrotów głowy.

Obejmuje: uczucie dzwonienia w uszach, podrażnienia uszu, ucisk uszny, nudności związane z kręceniem się w głowie lub zawrotami głowy

Nie obejmuje: funkcje przedsionka (b235); czucie bólu (b280)

\section{STRUKTURY CIAŁA LUDZKIEGO}

= Struktury ciała ludzkiego to jego części anatomiczne takie jak narządy, kończyny i ich elementy składowe.

\begin{tabular}{ll}
\hline S110 & Struktura mózgu \\
\hline S240 & Struktury ucha zewnętrznego \\
\hline S250 & Struktury ucha środkowego \\
\hline S260 & Struktury ucha wewnętrznego \\
\hline
\end{tabular}




\section{AKTYWNOŚCI I UCZESTNICZENIE}

Aktywność jest to wykonanie przez daną osobę zadania lub podjęcie działania.

Uczestniczenie jest to angażowanie się danej osoby w określone sytuacje życiowe.

Słuchanie

Zamierzone posługiwanie się zmysłem słuchu w celu odbioru bodźców słuchowych, jak np. podczas słuchania radia, muzyki lub wykładu.

d 240

Radzenie sobie ze stresem i innymi obciążeniami psychicznymi

Wykonywanie prostych lub złożonych i skoordynowanych działań, związanych z kontrolowaniem obciążeń psychicznych występujących podczas wykonywania zadań, które wiążą się z ponoszeniem znacznej odpowiedzialności, narażeniem na stres, czynniki zakłócające lub sytuacje kryzysowe, jak np. w trakcie kierowania pojazdem w czasie wielkiego natężenia ruchu ulicznego lub sprawowania opieki nad liczna grupa dzieci.

Obejmuje: ponoszenie odpowiedzialności; radzenie sobie ze stresem i sytuacjami kryzysowymi

Porozumiewanie się - odbieranie - wiadomości ustne

Pojmowanie dosłownego i domyślnego znaczenia wiadomości przekazywanych za pomocą języka mówionego, jak np. gdy rozumie się, że jakieś stwierdzenie dotyczy faktu lub jest wyrażeniem idiomatycznym.

Rozmowa

Rozpoczynanie, kontynuowanie i kończenie wymiany myśli i poglądów za pomocą języka mówionego, pisanego, migowego lub innych form języka, z jedną osobą lub większą liczbą ludzi znajomych lub obcych w kontaktach oficjalnych lub towarzyskich.

Obejmuje: rozpoczynanie, podtrzymywanie i kończenie rozmowy; rozmowa z jedna osoba lub wieloma ludźmi

Używanie urządzeń i technik służących do porozumiewania się

Wykorzystywanie urządzeń, technik i innych środków do porozumiewania się, np. używanie telefonu aby zadzwonić do przyjaciela.

Obejmuje: używanie urządzeń telekomunikacyjnych, używanie maszyn do pisania i technik do porozumiewania się

Tworzenie i utrzymywanie kontaktów opartych na więzi pokrewieństwa jak np. z członkami najbliższej rodziny, dalszą rodziną, przybraną i adoptowaną rodziną, przyrodnią rodziną i opartych na bardziej odległych związkach jak np. z dalszymi kuzynami lub prawnymi opiekunami.

Obejmuje: wzajemne zwiazki pomiędzy rodzicami a dzieckiem i pomiędzy dzieckiem a rodzicami, wzajemne związi pomiędzy rodzeństwem i wzajemne związki pomiędzy dalszą rodzina

d820

Kształcenie szkolne

Uzyskanie przyjęcia do szkoły, kształcenie, angażowanie się w związane ze szkołą obowiązki i prawa, przyswajanie materiału nauczania, realizowanie przedmiotów i innych wymogów programu szkolnego w szkole podstawowej i średniej włączając regularne uczęszczanie do szkoty, wspótprace z innymi uczniami, uzyskiwanie wskazówek od nauczycieli, przygotowanie, studiowanie i realizowanie przydzielonych zadań i projektów i czynienie postępów do dalszych etapów edukacji

d850

Zatrudnienie za wynagrodzeniem

Zaangażowanie we wszystkie aspekty pracy, na posadzie, w handlu, w ramach wykonywania określonego zawodu lub w innej formie zatrudnienia, za wynagrodzeniem, jako pracownik na etacie, w pełnym lub częściowym wymiarze czasu lub w formie samozatrudnienia, np. poszukiwanie i uzyskiwanie pracy, wykonywanie wymaganych zadań w pracy, przybywanie do pracy punktualnie zgodnie $z$ wymogami, nadzorowanie innych pracowników lub podleganie nadzorowi i podejmowanie wymaganych zadań samodzielnie lub w grupach.

Obejmuje: samozatrudnienie, zatrudnienie w częściowym lub petnym wymiarze czasu

Życie w społeczności lokalnej

Udział we wszystkich przejawach życia społecznego w społeczności lokalnej, jak np. zaangażowanie się w działalność organizacji charytatywnych, organizacji społecznych, lub profesjonalnych organizacjach pomocy socjalnej. Obejmuje: nieoficjalne i oficjalne stowarzyszenia, uroczystości

Nie obejmuje: praca bez wynagrodzenia (d855); rekreacja i organizacja czasu wolnego (920); religia i duchowa sfera życia (d930); życie polityczne i petnienie ról obywatelskich (d950) 
CZYNNIKI ŚRODOWISKOWE

= tworzą fizyczne i społeczne środowisko oraz system postaw, w którym żyją ludzie.

e125 Produkty $i$ technologie służące do porozumiewania się

Wyposażenie, produkty i technologie wykorzystywane przez ludzi do wysyłania i odbierania informacji, z włączeniem tych, które zostały specjalnie zaadaptowane lub zaprojektowane, umiejscowione wewnątrz, na ciele lub w pobliżu używającej je osoby.

Obejmuje: ogólne i wspomagające produkty i technologie używane do porozumiewania się

e250 Dźwięk

Zjawisko, które jest lub może być słyszalne takie jak huk, dzwonienie, toskot, śpiew, gwizd, wrzask i brzęczenie, o dowolnej głośności, barwie i tonacji i które może dostarczyć użytecznych lub mylnych informacji o świecie.

Obejmuje: poziom dźwięku i jakość dźwięku

e310 Najbliższa rodzina

Osoby spokrewnione przez urodzenie, małżeństwo lub inne związki uznawane zgodnie z normami kulturowymi za najbliższą rodzinę jak: małżonkowie, partnerzy, rodzice, rodzeństwo, dzieci, rodzina zastępcza, rodzice adopcyjni i dziadkowie. Nie obejmuje: dalszą rodzinę (e315); opiekunów asystentów osobistych (e340)

e355

Pracownicy fachowi ochrony zdrowia (profesjonaliści w ochronie zdrowia)

Wszyscy oferujący usługi w zakresie systemu ochrony zdrowia, jak: lekarze, pielęgniarki, położne, fizjoterapeuci, terapeuci zajęciowi, logopedzi, audiolodzy, protetycy, medyczni pracownicy socjalni.

Nie obejmuje: inni pracownicy fachowi (e360)

e410

Postawy członków najbliższej rodziny

Ogólne lub określone opinie i przekonania członków najbliższej rodziny o danej osobie lub o innych kwestiach (np. społecznych, politycznych i ekonomicznych), które wpływają na indywidualne zachowanie i działanie.

e460

Postawy społeczne

Ogólne lub określone opinie i przekonania wyrażane przeważnie przez ludzi kultury, społeczeństwo, subkulturowe lub inne grupy społeczne o innych osobach lub o innych kwestiach społecznych, politycznych i ekonomicznych, które wpływają na zachowanie i działania grupowe lub indywidualne.

e580

Usługi, systemy i polityka w zakresie ochrony zdrowia

Usługi, systemy i polityka dla zapobiegania i leczenia problemów zdrowotnych, zapewniania rehabilitacji medycznej

i promowania zdrowego stylu życia.

Nie obejmuje: usługi, systemy i polityka w zakresie ogólnego wsparcia społecznego (e575)

jest używany jako termin całościowy, zgodnie z funkcjonalnym modelem niepełnosprawności zawartym w ICF.

\section{Rehabilitacja audiologiczna po wszczepieniu implantu ślimakowego - badania diagnostyczne}

Funkcje i struktury ciała

W przypadku niedosłuchu odbiorczego niepełnosprawność słuchowa związana jest $\mathrm{z}$ uszkodzeniem komórek słuchowych w ślimaku [2]. Ślimak jest częścią ucha wewnętrznego, a w ICF jest sklasyfikowany w części „Struktury ciała ludzkiego" w rozdziale 2 , w pozycji struktury ucha wewnętrznego, które oznaczone są kodem $(\mathrm{s} 260)^{3}$ [1]. W przypadku użytkowników implantów ślimakowych większość komórek słuchowych jest zniszczona [2]. Taki deficyt sprawnych komórek słuchowych stanowi znaczne (kwalifikator s260.3) bądź skrajnie duże (kwalifikator s260.4) upośledzenie struktur ucha wewnętrznego, prowadząc do znacznego bądź skrajnie dużego upośledzenia funkcji słyszenia (kwalifikatory b230.3; b230.4). Częściowa kompensacja utraconej funkcji ciała (słyszenia) możliwa jest dzięki zastosowaniu odpowiedniego medycznego środka technicznego, którym w tym przypadku jest implant ślimakowy. Dzięki stymulacji elektrycznej zakończeń nerwu słuchowego możliwe jest przekazanie części informacji o dźwięku do ośrodkowego układu nerwowego (OUN) [27]. Niestety konsekwencją niedosłuchu odbiorczego jest wystąpienie w okresie poprzedzającym wszczepienie implantu stanu deprywacji sensorycznej. Stan ten w następstwie mechanizmów neuroplastyczności, których zindywidualizowany charakter będzie zależał od historii choroby pacjenta, może doprowadzić do zmian organizacji części układu nerwowego zaangażowanego w przetwarzanie informacji słuchowej, zlokalizowanych w obszarach struktur płatów korowych - s110 (zwłaszcza płata skroniowego - s11001), struktur śródmózgowia - s1101, międzymózgowia - s1102, pnia mózgu s1105 i nerwu słuchowego - s1106 [1,28]. Należy liczyć się z tym, że zmiany te mogą prowadzić do funkcjonalnych ograniczeń w przetwarzaniu informacji słuchowej, powstającej dzięki stymulacji elektrycznej w obrębie ucha wewnętrznego, dokonywanym przez poszczególne struktury układu nerwowego [29]. A zatem nawet w wyidealizowanym przypadku, gdy dzięki implantowi udałoby się całkowicie przywrócić funkcję biologiczną komórek słuchowych, wystąpienie problemów z przetwarzaniem informacji sensorycznej na kolejnych piętrach ośrodkowego układu nerwowego mogłoby znacznie zmniejszyć możliwości kompensacji funkcji słyszenia.

\footnotetext{
3. Kategorie oceny zaczerpnięte zostały z polskiej wersji językowej Klasyfikacji ICF zatwierdzonej przez WHO [1].
} 


\section{Ocena funkcjonalna struktur układu słuchowego}

Aby możliwa była skuteczna kompensacja utraconej funkcji słyszenia za pomocą implantu ślimakowego, konieczne jest przeprowadzenie indywidualnie dla każdego pacjenta doboru i optymalizacji parametrów stymulacji elektrycznej [30]. Od parametrów tej stymulacji, takich jak poziom stosowanego ładunku elektrycznego, częstość impulsów stymulujących, pozycja kontaktu elektrycznego umieszczonego na wiązce elektrody stymulującej, zależy zarówno ilość i jakość informacji o dźwięku przekazywanej do OUN, jak i efektywność przetwarzania informacji słuchowej w wymienionych powyżej strukturach OUN [31]. Dopasowanie parametrów stymulacji prowadzi się indywidualnie, ponieważ deficyt funkcji poszczególnych struktur może być u każdego pacjenta inny [32]. Deficyty te zależą bowiem od wielu czynników, takich jak moment wystąpienia niedosłuchu (wrodzony, nabyty we wczesnym dzieciństwie, w późnym dzieciństwie, w wieku dorosłym lub w wieku podeszłym), charakter niedosłuchu stały bądź zmienny w czasie, stopień niedosłuchu czy etiologia [28,32]. Zatem ocena możliwości funkcjonowania struktur układu słuchowego stymulowanego elektrycznie jest kluczowym i pierwszym elementem rozpoczynającym proces doboru i optymalizacji parametrów stymulacji elektrycznej, wykorzystywanej do kompensacji deficytów słyszenia [33]. $\mathrm{W}$ trakcie przebiegu procedury diagnostycznej ustalane są też czynniki, które ograniczają możliwości kompensacji słyszenia za pomocą implantu. Do badań funkcji poszczególnych struktur elektrycznie stymulowanego układu słuchowego wykorzystywane są nowoczesne, nieinwazyjne techniki diagnostyczne [34].

\section{Ocena struktur zaimplantowanego ucha wewnętrznego (s260)}

W celu określenia pozycji wiązki elektrody w ślimaku oraz integralności struktur ślimaka (s260) wykonywane są badania diagnostyczne. Na podstawie wyniku tomografii komputerowej można między innymi ocenić, czy położenie elektrod względem struktur nerwu słuchowego zapewnia możliwość prowadzenia efektywnej stymulacji elektrycznej tego nerwu [35]. Telemetria impedancyjna, będąc pomiarem impedancji elektrycznej elektrod wszczepionego implantu, pozwala na zdiagnozowanie ewentualnych zwarć między elektrodami (mała impedancja) lub uszkodzeń połączenia elektroda-implant (wysoka impedancja) [33]. Analiza zmian impedancji w czasie może dostarczyć informacji o niektórych zmianach patologicznych, takich jak postępująca fibroza czy osyfikacja ślimaka, jak również o wystąpieniu stanów zapalnych ucha wewnętrznego [36]. Wystąpienie tych stanów może powodować znaczne ograniczenie możliwości kompensacji funkcji słyszenia.

\section{Ocena struktur nerwu słuchowego (s260)}

Diagnostyki funkcjonalnej struktur nerwu słuchowego dokonuje się na podstawie oceny całościowego potencjału czynnościowego nerwu słuchowego (ang. Electrically Evoked Compound Action Potential, EECAP) [37]. Funkcją biologiczną nerwu słuchowego jest bowiem przesyłanie informacji słuchowej. Przesyłanie to odbywa się za pośrednictwem potencjałów czynnościowych, będących przejściową zmianą potencjału błony komórki neuronalnej [38]. Elektrycznie wywołany całościowy potencjał czynnościowy powstaje jako odpowiedź neuronalna na impuls elektryczny przesyłany w okolice zakończeń nerwu słuchowego za pomocą elektrody implantu [39]. Analiza progów EECAP, funkcji narastania amplitudy, morfologii zapisu pozwala na ocenę funkcjonalną elektrycznie stymulowanego nerwu słuchowego [40] ${ }^{4}$.

Ocena struktur pnia mózgu (s1105); struktur śródmózgowia (s1101); międzymózgowia (s1102); struktur płatów korowych (s110)

Badaniem, które może być wykorzystane do oszacowania statusu funkcjonalnego struktury pnia mózgu, jest rejestracja elektrycznie wywołanego odruchu mięśnia strzemiączkowego [41]. Wykorzystywany jest tu łuk odruchowy, który obejmuje strukturę stymulowanego elektrycznie nerwu słuchowego oraz struktury pnia mózgu takie jak: jądra ślimakowe, jądra oliwki górnej oraz jądra ruchowe nerwu twarzowego [42].

Pomiar elektrycznie wywołanych potencjałów słuchowych (ang. Electrically Evoked Auditory Potentials, EEAP) wykonywany jest po to, aby monitorować u pacjentów implantowanych funkcję przetwarzania informacji słuchowej na różnych piętrach OUN. Potencjały, które pojawiają się do około $10 \mathrm{~ms}$ po podaniu bodźca elektrycznego, niosą informacje o funkcji struktur pnia i śródmózgowia, a potencjały powstające po czasie dłuższym niż $10 \mathrm{~ms}$ świadczą o aktywności struktur międzymózgowia i kory słuchowej $[43,44]$.

Z uwagi na zasadę sekwencyjności przetwarzania informacji w układzie słuchowym (informacja przetwarzana na niższym poziomie przesyłana jest na wyższy poziom) nieprawidłowy wynik badania danej struktury może świadczyć zarówno o stanie patologicznym w obrębie tej struktury, jak i o deficycie przetwarzania słuchowego w strukturach poprzedzających [2].

\section{Rehabilitacja audiologiczna po wszczepieniu implantu ślimakowego - kompensacja funkcji słyszenia}

Funkcje słyszenia zgodnie z klasyfikacją ICF obejmują: wykrywanie dźwięków rozumiane jako odczuwanie obecności dźwięków (b2300); rozróżnianie dźwięków, w tym rozróżnianie wysokości tonu, głośności i jakości dźwięków (b2301); umiejscowienie źródła dźwięku (b2302); lateralizacja dźwięku (b2303), odróżnianie mowy pozwalające rozpoznać język mówiony i odróżnić go od innych dźwięków (b2304) [1].

\section{Funkcja wykrywania dźwięków}

Dzięki właściwie dobranym na podstawie wyników badań diagnostycznych parametrom stymulacji elektrycznej możliwe jest prawidłowe dopasowanie procesora mowy, które pozwala na całkowitą kompensację utraconej w następstwie niedosłuchu funkcji wykrywania dźwięków

4. zob. A. Walkowiak i wsp. Symulacja słyszenia pacjenta z implantem ślimakowym w tym numerze „Nowej Audiofonologii”. 
u pacjentów z całkowitą lub częściową głuchotą [7,45]. Tylko w bardzo nielicznych przypadkach wada lub stan patologiczny w obszarze struktur ucha wewnętrznego bądź nerwu słuchowego uniemożliwia kompensację tej funkcji. W celu potwierdzenia możliwości prawidłowego wykrywania dźwięków po wszczepieniu implantu i aktywacji procesora mowy wykonuje się badanie audiometrii tonalnej w polu swobodnym [7,33]. W przypadku dzieci dobór odpowiedniej metody przeprowadzenia tego badania zależy od wieku chronologicznego/rozwojowego dziecka. Reakcje słuchowe dzieci do około piątego miesiąca życia mogą być ocenione $\mathrm{z}$ wykorzystaniem audiometrii obserwacyjnej BOA (ang. Behavioral Observation Audiometry) [2]. Na tym etapie rozwoju dziecka reakcje nie odzwierciedlają progu słyszenia, lecz próg reakcji dziecka na dźwięk występujący powyżej progu słyszenia. Behawioralnej oceny progu słyszenia można dokonać już u dzieci powyżej piątego miesiąca życia $\mathrm{z}$ wykorzystaniem wzmocnienia wizualnego - VRA (ang. Visual Reinforcement Audiometry) lub audiometrii zabawowej - CPA (ang. Conditioned Play Audiometry) (pow. 2 rż.) [2].

\section{Funkcja rozróżniania głośności}

W większości przypadków za sprawą odpowiedniej stymulacji elektrycznej udaje się również skompensować funkcję rozróżniania głośności dźwięków [46]. W tym celu określa się zakres tzw. dynamiki słyszenia elektrycznego podczas badania psychofizycznego wyznaczania funkcji narastania głośności (FNG) przy stymulacji elektrycznej prowadzonej przez wybrany kontakt elektrody implantu $[33,47]$. Na podstawie FNG dobierane są parametry stymulacji elektrycznej takie jak: wartość ładunku elektrycznego odpowiadająca progowi słyszenia (ang. threshold, THR); wartość ładunku elektrycznego odpowiadająca poziomowi komfortowego słyszenia (ang. Most Comfortable Laudness, MCL); kształt kompresji poziomu ciśnienia akustycznego [47].

Do weryfikacji uzyskiwanej funkcji słyszenia wykorzystuje się badanie skalowania głośności metodą würzburską (niem. Würzburger Hörfeld Skalierung, WHF) [48]. Metoda ta pozwala na bezpośrednie porównanie uzyskiwanych wyników $\mathrm{z}$ wynikami normatywnymi wyznaczonymi u osób z prawidłowym słuchem $[27,48]$. U części pacjentów obserwuje się nieprawidłowe rozróżnianie głośności i brak możliwości pełnej kompensacji tej funkcji poprzez dobór parametrów stymulacji w procesie ustawiania procesora mowy [27]. Pacjenci ci charakteryzują się przeważnie długim okresem deprywacji sensorycznej spowodowanym niedosłuchem nabytym, który wystąpił wiele lat przed wszczepieniem implantu, bądź niedosłuchem wrodzonym. Deprywacja sensoryczna powoduje deficyt przetwarzania słuchowego w strukturach OUN [28,32]. Dzięki dobrze zaprojektowanemu treningowi słuchowemu możliwe jest u wielu pacjentów uruchomienie w OUN mechanizmów kompensacyjnych, w wyniku których dochodzi do całkowitego lub częściowego wyrównania skutków działania czynnika szkodliwego, którym jest tu deprywacja sensoryczna [48]. U niektórych pacjentów niedosłuch może również oznaczać upośledzenie struktur nerwu słuchowego, polegające na znacznym zmniejszeniu liczby sprawnych komórek neuronalnych [28]. Może to prowadzić do zawężenia dynamiki słyszenia elektrycznego. W takich przypadkach ustawienie procesora, które prowadziłoby do prawidłowej dyskryminacji głośności, może być niemożliwe. Odpowiedni trening słuchowy może wyzwolić naturalne zdolności kompensacyjne i pomimo częściowo uszkodzonego nerwu słuchowego spowodować odtwarzanie utraconych możliwości dyskryminacji głośności [49].

\section{Funkcja rozróżniania wysokości tonu}

Pełna kompensacja funkcji rozróżniania wysokości tonu za pomocą implantu ślimakowego jest niemożliwa [31]. Biologiczna funkcja ślimaka pozwalająca na rozróżnianie wysokości tonu oparta jest na zasadzie miejsca pobudzenia i zasadzie periodyczności [50]. Zasada miejsca polega na tym, że tony o różnych częstotliwościach prowadzą do pobudzenia różnych grup neuronów o określonych częstotliwościach charakterystycznych [50]. Dyskryminacja wysokości tonów o podobnych częstotliwościach możliwa jest wówczas, gdy miejsca maksimów pobudzenia odległe są jedynie o 12 neuronów [51]. Wiadome jest, że do błony podstawnej dochodzą zakończenia około 30000 komórek neuronalnych. Wynika $\mathrm{z}$ tego, że w przypadku słuchu prawidłowego występuje około 2500 separowanych miejsc na błonie podstawnej, potrzebnych do realizacji funkcji rozróżniania tonów [51]. W przypadku implantu ślimakowego zasada miejsca pobudzenia realizowana jest przez stymulację elektryczną prowadzoną za pośrednictwem kilkunastu kontaktów elektrodowych, którym przyporządkowuje się określone częstotliwości tonu. Kontaktom elektrodowym znajdującym się w zakręcie podstawnym ślimaka przyporządkowane są częstotliwości wysokie, a kontaktom w części szczytowej przyporządkowane są częstotliwości niskie [52]. Liczba separowanych miejsc uzyskanego elektrycznie pobudzenia jest $\mathrm{z}$ reguły dużo mniejsza od liczby kontaktów, z uwagi na przestrzenny rozpływ ładunku oraz z powodu częściowego upośledzenia struktur nerwu słuchowego [53] $]^{5}$. Liczba separowanych miejsc pobudzenia jest zatem kilkaset razy mniejsza niż w słuchu prawidłowym.

Drugi sposób realizowania funkcji dyskryminacji tonu, oparty na zasadzie periodyczności, nie jest realizowany przez typowe systemy implantów ślimakowych. W systemach tych bowiem wykorzystuje się przetwarzanie dźwięku na bodziec elektryczny (tzw. strategie kodowania) oparte na algorytmie wokodera pasmowego [27,31]. Algorytm ten pozwala na przeniesienie do nerwu informacji zawartej w obwiedni sygnałów, natomiast informacje o strukturze czasowej sygnału, potrzebne do realizacji funkcji dyskryminacji tonu opartej na zasadzie periodyczności, są pomijane [31]. Obecnie tylko w jednym typie systemu implantu podjęto próbę implementacji strategii kodowania, która opracowana została z myślą o przekazywaniu do nerwu słuchowego informacji o strukturze czasowej sygnału (ang. Fine Structure Processing, FSP) [54]. Deficyt rozróżniania tonów przez osoby z implantami ślimakowymi może być kompensowany do pewnego stopnia w wyniku zmian w OUN wywołanych poprzez odpowiedni trening słuchowy [55]. Możliwości takiej kompensacji zależą od parametrów prowadzonego treningu (częstości) jak również od indywidualnego zakresu neuroplastyczności u danego pacjenta [55]. U części pacjentów, podobnie jak w przypadku funkcji

5. zob. A. Walkowiak i wsp. Symulacja styszenia pacjenta z implantem ślimakowym w tym numerze „Nowej Audiofonologii”. 
rozróżniania głośności, poprzedzająca implantację deprywacja sensoryczna może spowodować zmiany w OUN, które mogą prowadzić do zaburzenia funkcji rozróżniania tonów przywracanej za pomocą implantu [32].

\section{Funkcja rozróżniania jakości dźwięku}

Podobnie jak w przypadku rozróżniania tonów, funkcja rozróżniania jakości dźwięku może być tylko częściowo skompensowana dzięki implantowi ślimakowemu. Ograniczenia techniczne wynikające z przetwarzania dźwięku na stymulację elektryczną, takie jak: rozpływ przestrzenny ładunku elektrycznego w ślimaku, na którego wpływ ma zarówno odległość elektrod od zakończeń nerwu słuchowego, jak i impedancja tkanek wokół elektrod, upośledzenie struktur nerwu słuchowego i powstałe w wyniku deprywacji upośledzenie OUN mogą w bardzo różnym stopniu - od niewielkiego do skrajnie dużego - upośledzać odzyskiwaną dzięki implantowi funkcję rozróżniania jakości dźwięku [31].

Funkcja rozróżniania umiejscowienia źródła dźwięku oraz funkcja lateralizacji dźwięku

Niewielkie różnice natężenia lub czasu dotarcia dźwięków do każdego z uszu wykorzystywane są przez układ słuchowy do lokalizacji dźwięku [50,51]. Zatem, aby możliwa była kompensacja funkcji rozróżniania umiejscowienia źródła dźwięku oraz funkcja lateralizacji dźwięku, u pacjentów z głębokim niedosłuchem konieczne jest wykonanie obustronnej implantacji [56]. Ze względu na to, że implanty ślimakowe przekazują do nerwu słuchowego ograniczoną ilość informacji zarówno o natężeniu, jak i parametrach czasowych sygnału, funkcje te mogą być jedynie częściowo kompensowane za pośrednictwem implantów [31]. $\mathrm{W}$ przypadku osób dorosłych $\mathrm{z}$ jednostronną wrodzoną głuchotą, które w wieku dorosłym utraciły słuch w drugim uchu, zastosowanie obuuszne implantów nie prowadzi do kompensacji funkcji rozróżniania umiejscowienia źródła dźwięku oraz funkcji lateralizacji dźwięku. Brak możliwości kompensacji wynika ze zmian w organizacji OUN, które dokonały się w okresie krytycznym dla rozwoju tych funkcji w wyniku jednostronnej deprywacji sensorycznej [57].

Funkcja odróżniania mowy pozwalająca rozpoznać język mówiony i odróżnić go od innych dźwięków

Funkcja ta u większości pacjentów z głębokim niedosłuchem przywracana jest za pośrednictwem implantu ślimakowego. Za pomocą stymulacji elektrycznej możliwe jest bowiem przekazanie do nerwu słuchowego takiej ilości informacji o sygnale, która pozwala na rozpoznanie mowy i odróżnienie jej od innych dźwięków [31].

\section{Rehabilitacja audiologiczna po wszczepieniu implantu ślimakowego - eliminacja ograniczeń w aktywności}

Zgodnie z ICF aktywność jest to wykonanie przez daną osobę zadania lub podjęcie działania [1]. W opracowanych listach kluczowych dla niedosłuchu (tabela 1) ograniczenia spowodowane niesprawnością słuchową dotyczą najczęściej aktywności związanych ze słuchaniem (d115) oraz odbieraniem wiadomości ustnej (d310). Ponadto wymienione są dwie aktywności: radzenie sobie ze stresem i innymi obciążeniami psychicznymi (d240) oraz używanie urządzeń i technik służących do porozumiewania się (d310) jako istotne w przeciwdziałaniu negatywnym skutkom niepełnosprawności słuchowej. Możliwości eliminacji ograniczeń w tych aktywnościach za pomocą implantu ślimakowego zależą zarówno od tego, w jakim stopniu funkcje słyszenia zostały skompensowane, jak i od czynników kontekstowych zewnętrznych i wewnętrznych. Czynniki kontekstowe zewnętrzne i wewnętrzne zostaną szczegółowo omówione w następnych paragrafach.

\section{Słuchanie}

Słuchanie to zamierzone posługiwanie się zmysłem słuchu w celu odbioru bodźców słuchowych np. podczas słuchania radia, muzyki lub wykładu [1]. Słuchanie wymaga uwagi słuchowej i związane jest z wysiłkiem umysłowym (słuchowym) [58]. Wysiłek ten wzrasta, jeśli aktywność słuchowa dotyczy wybranego dźwięku (źródła dźwięku), który występuje w towarzystwie innych dźwięków (źródeł) [59]. Wybiórcze słuchanie polegające na świadomym przeniesieniu uwagi słuchowej na określone dźwięki i ignorowaniu innych, występujących równocześnie dźwięków jest kluczową aktywnością pozwalającą nie tylko na uczestniczenie w procesie komunikacji, lecz także na orientację w tak zwanej przestrzeni dźwiękowej koniecznej do uzyskania kontaktu (związku) z otoczeniem [60]. Brak tego kontaktu może prowadzić do poczucia wyobcowania i utrudnić uczestniczenie w wielu sytuacjach życiowych [61] ${ }^{6}$.

Częściowa kompensacja za pomocą implantu ślimakowego utraconych funkcji słyszenia prowadzi do zmniejszenia, a nie do wyeliminowania ograniczeń w słuchaniu [62]. Przy korzystaniu ze stymulacji elektrycznej nerwu słuchowego nie wszystkie informacje o dźwięku przekazywane są do OUN [31]. Dlatego też słuchanie za pośrednictwem implantu może wiązać się $\mathrm{z}$ większym, w porównaniu ze słuchem prawidłowym, wysiłkiem słuchowym $[63,64]$. U wielu pacjentów bezpośrednio po aktywacji systemu implantu ślimakowego kompensacja funkcji wykrywania dźwięków, przy często występującym w początkowej fazie rehabilitacji braku odpowiedniej kompensacji funkcji rozróżniania dźwięków, umiejscowienia źródła dźwięku czy lateralizacji dźwięku nie ułatwia słuchania, zwłaszcza w sytuacji złożonych krajobrazów dźwiękowych. W takich sytuacjach zalecany jest trening percepcyjny ukierunkowany na dyskryminację i identyfikację dźwięków otoczenia. W przypadku pacjentów z częściową głuchotą, u których funkcja wykrywania dźwięków niskich była obecna przed wszczepieniem implantu, przywrócenie funkcji wykrywania dźwięków wysokich może prowadzić początkowo do jeszcze większych utrudnień w słuchaniu [65]. Dzieje się tak najczęściej w sytuacji wystąpienia czynników zewnętrznych związanych z obecnością wysokoczęstotliwościowych dźwięków zakłócających (np. szelesty, brzęk naczyń, sztućców). Doświadczenia słuchowe ograniczone

\footnotetext{
6. zob. A. Obszańska i wsp. Postrzeganie dźwięków otoczenia w subiektywnej ocenie użytkowników implantów ślimakowych przed aktywacja i po aktywacji systemu implantu ślimakowego w tym numerze „Nowej Audiofonologii”.
} 
przed wszczepieniem implantu jedynie do niskich częstotliwości mogą powodować zmiany patologiczne w przetwarzaniu słuchowym dokonującym się w OUN. Zmiany te są źródłem powstania nadmiernego wysiłku słuchowego podczas przetwarzania dźwięków wysokich, występującego po przywróceniu funkcji wykrywania tych dźwięków po wszczepieniu implantu [66]. Przedłużający się wysiłek może powodować zmęczenie oraz poczucie obciążenia psychicznego towarzyszące wykonywaniu zadań dnia codziennego.

Zatem dobór parametrów stymulacji, prowadzony w trakcie ustawiania procesora mowy, musi być ukierunkowany nie tylko na kompensację funkcji słyszenia, lecz także musi uwzględniać konieczność wyeliminowania nadmiernego wysiłku słuchowego, który może prowadzić do poważnych utrudnień w słuchaniu za pośrednictwem implantu [33]. Wysiłek słuchowy może również być ograniczany poprzez prowadzenie odpowiedniego treningu, nastawionego na usprawnienie funkcji biologicznej przetwarzania informacji słuchowej w OUN $[67,68]$. Stosowane jest również poradnictwo psychologiczne po to, by ukierunkować pacjenta na odpowiednie wykorzystywanie innych niż słyszenie funkcji ciała ludzkiego, aby wysiłek słuchowy nie ograniczał aktywności słuchowej [25]. Przy opracowywaniu list ICF dla niedosłuchu do funkcji tych zaliczono: funkcje temperamentu i osobowości (b126), funkcje uwagi (b140), funkcje emocjonalne (b152) (tabela 1).

Zmiany ograniczeń w słuchaniu występujące po aktywacji systemu implantu muszą być u każdego pacjenta indywidualnie określane, aby móc optymalizować zarówno ustawienia procesora mowy, jak i przebieg treningów słuchowych i poradnictwa. Do wyznaczenia tych zmian wykorzystuje się zwalidowane narzędzia kwestionariuszowe, pozwalające na pomiar ograniczeń w słuchaniu. W przypadku pacjentów dorosłych stosuje się kwestionariusz $\mathrm{ABHAB}$ oraz kwestionariusz „Karta dźwięków”, a w przypadku dzieci kwestionariusz LittlEARS $[69,70]^{8}$.

\section{Odbieranie wiadomości ustnej (rozumienie)}

Odbieranie wiadomości ustnej oznacza pojmowanie dosłownego i domyślnego znaczenia wiadomości przekazywanych za pomocą języka mówionego (d310) (tabela 1). System implantu ślimakowego, częściowo kompensując funkcje słyszenia, przekazuje do OUN zniekształconą w różnym stopniu informację o sygnale mowy [31]. Ponadto funkcje biologiczne przetwarzania informacji w OUN mogą być upośledzone przez deprywację sensoryczną spowodowaną niedosłuchem, powodując degradację informacji o dźwiękach mowy [28,29,32]. Zatem rozumienie mowy może być $\mathrm{w}$ różnym stopniu upośledzone i zależne zarówno od ilości informacji o sygnale mowy przekazywanej do OUN za pośrednictwem implantu, jak i od kondycji OUN. Prowadzone badania nad rozumieniem mowy po wszczepieniu implantu wskazują na znaczne zmiany w rozumieniu mowy w ciągu roku po wszczepieniu implantu [71]. Obserwowalny wzrost rozumienia świadczy o plastyczności OUN, która pozwala na uruchomienie odpowiednich mechanizmów kompensacyjnych, w rezultacie których przetwarzanie informacji o dźwiękach mowy w OUN dostosowuje się do warunków degradacji informacji związanej ze stymulacją elektryczną [32]. Dlatego też dobór parametrów stymulacji w trakcie ustawiania systemu implantu powinien być tak prowadzony, aby wzmacniać mechanizmy kompensacyjne w OUN [33,72]. Mechanizmy te uruchamiane są również poprzez treningi percepcyjne [73]. Zmiany w rozumieniu mowy muszą być monitorowane zarówno w celu weryfikacji poprawności ustawienia procesora mowy, jak i skuteczności prowadzonych treningów percepcyjnych. Możliwości rozumienia mowy szacuje się na podstawie testów diagnostycznych dyskryminacji słów jednosylabowych lub testów zdaniowych [74].Wskaźnikiem możliwości rozumienia mowy u dzieci są wyniki testów percepcji mowy, polegających na kojarzeniu słowa $\mathrm{z}$ jego reprezentacją graficzną, takich jak np. Adaptacyjny Test Rozumienia Mowy - AAST (ang. Adaptive Auditory Speech Test) [75]. Ocena progu rozumienia mowy wyznaczona testem AAST pozwala wnioskować zarówno o czułości słuchu, jak i o możliwości interpretacji informacji akustycznej. Ponadto obniżanie się w czasie progu rozumienia mowy świadczy o rosnących możliwościach dziecka w zakresie wykorzystania składowych sygnału mowy do jej rozumienia.

Rozumienie wiadomości ustnej jest jednym z najtrudniejszych i najbardziej złożonych zadań poznawczych związanych z interpretacją danych sensorycznych. Do realizacji tej aktywności oprócz funkcji słyszenia uruchamiane są ogólne funkcje psychiczne niezbędne do rozumienia (b117), funkcje uwagi (b140), wyższe funkcje poznawcze (b164), funkcje językowe (b167), funkcje semantycznej pamięci języka (b1441) oraz funkcje pamięci krótkotrwałej (b1440) [76]. Ponieważ funkcje słyszenia są jedynie częściowo kompensowane dzięki implantowi w wyniku procesu adaptacji, powyżej wymienione funkcje powinny być właściwie wykorzystywane, aby zrealizować funkcję rozumienia mowy [77]. Zaangażowanie, czasem na granicy przeciążenia, poszczególnych funkcji doprowadza w wielu sytuacjach do wystąpienia nadmiernego wysiłku wskutek obciążenia poznawczego [78]. Edukacja pacjenta, podnosząca jego świadomość dotyczącą przyczyn problemów $\mathrm{z}$ rozumieniem występujących po wszczepieniu implantu oraz powodów braku możliwości zniesienia wszystkich ograniczeń w odbieraniu wiadomości ustnej, ułatwia świadome uczestnictwo pacjenta w procesie rehabilitacji, zwiększając jej skuteczność [79]. Konieczne jest również prowadzenie poradnictwa nakierowanego na przyswajanie strategii odbioru przekazu ustnego, które mogą zmniejszyć wysiłek umysłowy [80]. Aby przyspieszyć proces adaptacji ukierunkowany na wykorzystanie funkcji pozasłuchowych dla potrzeb rozumienia mowy, zalecane są treningi funkcji poznawczych i funkcji pamięci operacyjnej $[81,82]$. Zrozumienie przekazu językowego przeciąża często pamięć operacyjną, dlatego zgodnie z teorią Danemana i Carpentera

\footnotetext{
7. zob. A. Obszańska i wsp. Postrzeganie dźwięków otoczenia w subiektywnej ocenie użytkowników implantów ślimakowych przed aktywacją i po aktywacji systemu implantu ślimakowego w tym numerze „Nowej Audiofonologii”.

8. zob. A. Obrycka i wsp. Wykorzystanie kwestionariusza LittlEARS do oceny skuteczności interwencji związanej ze stosowaniem implantu ślimakowego u małych dzieci z głębokim niedosłuchem oraz Ocena rozwoju słuchowego dzieci z głębokim niedosłuchem, którym wszczepiono implant ślimakowy we wczesnym dzieciństwie w tym numerze „Nowej Audiofonologii”.
} 
konsekwencją mniejszej pojemności tego magazynu będą deficyty w zrozumieniu, zwłaszcza w przebiegu procesów, których zadaniem jest integracja pojedynczych słów, wyrażeń i zdań w spójną i logiczną całość [83]․

\section{Radzenie sobie ze stresem i innymi obciążeniami psychicznymi}

Nauka stosownych strategii radzenia sobie ze stresem może być potrzebna pacjentom zwłaszcza w pierwszym roku po wszczepieniu implantu. Osiągnięcie zamierzonych celów rehabilitacyjnych u użytkowników implantów związane jest $\mathrm{z}$ koniecznością wprowadzenia zmian w życiu pacjenta, dotyczących zwłaszcza aktywności słuchowej i uczestnictwa w komunikacji werbalnej. Częściowa tylko kompensacja funkcji słyszenia przez implant ślimakowy oraz utrwalone i nieadekwatne do nowej sytuacji, występującej po wszczepieniu implantu, nawyki i strategie komunikacyjne mogą być źródłem obciążeń psychicznych. Inną, dominującą zwłaszcza w początkowym okresie po aktywacji systemu implantu, przyczyną obciążeń psychicznych jest nadmierny wysiłek słuchowy. Dlatego też konieczne jest stosowanie różnych form rehabilitacji psychologicznej, skoncentrowanych na psychicznych funkcjach i problemach osoby niepełnosprawnej [84].

\section{Używanie urządzeń i technik służących do porozumiewania się}

Ograniczenia w tej aktywności występujące po wszczepieniu implantu dotyczą głównie używania telefonu. W ramach rehabilitacji audiologicznej organizowane są dla pacjentów odpowiednie szkolenia związane $\mathrm{z}$ nabywaniem umiejętności prowadzenia rozmów telefonicznych $\mathrm{z}$ wykorzystaniem procesora mowy [33].

\section{Rehabilitacja audiologiczna po wszczepieniu implantu ślimakowego - eliminacja ograniczeń w uczestnictwie}

Uczestniczenie, zgodnie z definicją ICF, to zaangażowanie w sytuację życiową [1]. W listach kluczowych ICF dla niedosłuchu wymienionych jest 5 wybranych sytuacji życiowych, w których osoba $\mathrm{z}$ niepełnosprawnością słuchową może mieć problemy $\mathrm{z}$ angażowaniem się. Sytuacje te to: rozmowa (d350), tworzenie rodziny (d760), kształcenie szkolne (d820), zatrudnienie za wynagrodzeniem (d820), życie w społeczności lokalnej (d910). Na podstawie prowadzonych badań wykazano, że w tych konkretnych sytuacjach życiowych niedosłuch jest najczęściej wskazywaną przyczyną ograniczeń w uczestnictwie $[21]^{10}$. Dlatego też, aby pomóc osobom po wszczepieniu implantu przezwyciężyć ograniczenia w uczestnictwie, w ramach rehabilitacji audiologicznej prowadzona jest, oprócz rehabilitacji fizycznej (medycznej), rehabilitacja psychologiczna i społeczna [85].

\section{Czynniki kontekstowe zewnętrzne}

Czynniki środowiskowe tworzą fizyczne i społeczne środowisko oraz system postaw, w którym żyją ludzie [1]. Na podstawie listy kluczowej ICF dla niedosłuchu, czynniki kontekstowe zewnętrzne wpływające w największym stopniu na aktywność i uczestnictwo osoby niepełnosprawnej słuchowo to: dźwięki (e250), produkty i technologie służące do porozumiewania się (e125), najbliższa rodzina (e310), postawy członków najbliższej rodziny (e410), postawy społeczne (e460), profesjonaliści w ochronie zdrowia (355), usługi, systemy i polityka w zakresie ochrony zdrowia (e580) (tabela 1). Modelowanie środowiska i próba jego zmiany w kierunku eliminacji ograniczeń aktywności i uczestnictwa, których doświadczają użytkownicy implantów ślimakowych, jest zadaniem koniecznym, ale często bardzo złożonym i trudnym [86]. W pierwszej kolejności podczas rehabilitacji audiologicznej podejmowane są wysiłki służące kształtowaniu środowiska na poziomie indywidualnym, będącym bezpośrednim otoczeniem użytkownika implantu [1]. Fizyczne cechy tego środowiska, które mogą zarówno ułatwiać, jak i utrudniać aktywność i uczestnictwo, to dźwięki (e580). Postrzeganie dźwięków zależy w dużej mierze od ustawienia systemu implantu ślimakowego, klasyfikowanego zgodnie z ICF jako produkty i technologie służące do porozumiewania się umiejscowione wewnątrz lub/i na ciele (e125) [1]. Zatem ustawienie procesora mowy pozwala na modelowanie środowiska poprzez modyfikowanie oddziaływania jego fizycznych cech na użytkownika implantu ${ }^{11}$. Środowisko indywidualne, zgodnie z ICF, obejmuje bezpośredni kontakt osobisty $z$ innymi osobami takimi jak: rodzina (e310), znajomi, rówieśnicy i osoby obce. Drugim podstawowym sposobem wpływania na czynniki środowiskowe wykorzystywanym w rehabilitacji audiologicznej jest działalność edukacyjna oraz poradnictwo o charakterze eksperckim, pozwalające na zmianę wielu czynników środowiskowych. W ramach tej działalności przekazywane są, zgodnie z zasadami EBM (ang. Evidence Based Medicine), informacje oparte na wynikach badań naukowych, dotyczące różnych aspektów użytkowania implantów ślimakowych, a zwłaszcza możliwej do uzyskania kompensacji funkcji słyszenia i jej deficytów po zastosowaniu implantu ślimakowego $[33,87]$. Wiedza o ograniczeniach tej kompensacji, np. problemy z rozumieniem mowy w hałasie przy relatywnie bezproblemowym rozumieniu w ciszy, może ułatwić kształtowanie najbliższego otoczenia, takiego jak dom, szkoła czy praca, poprzez modyfikację postaw członków najbliższej rodziny (e410) i postaw społecznych (e460) w taki sposób, aby użytkownikowi implantu ułatwić aktywność i uczestnictwo.

W rehabilitacji audiologicznej konieczne jest również uwzględnienie środowiska $\mathrm{z}$ poziomu społecznego [1]. Poziom ten dotyczy między innymi usług, systemów i polityki w zakresie ochrony zdrowia (e580) oraz profesjonalistów w ochronie zdrowia (e355). Na każdym etapie

\footnotetext{
9. zob. J. Putkiewicz i wsp. Pomiar pamięci operacyjnej z zastosowaniem systemu komputerowego u pacjentów implantowanych - ocena trafności testu w tym numerze „Nowej Audiofonologii”.

10. zob. M. Zgoda i wsp. Analiza porównawcza osiagnięć szkolnych trzynastolatków korzystających z implantu ślimakowego wszczepionego im przed ukończeniem 3 roku życia i styszących rówieśników w tym numerze „Nowej Audiofonologii”.

11. zob. A. Obszańska i wsp. Postrzeganie dźwięków otoczenia w subiektywnej ocenie użytkowników implantów ślimakowych przed aktywacją i po aktywacji systemu implantu ślimakowego w tym numerze „Nowej Audiofonologii”.
} 
i poziomie pracy z osobą niedosłyszącą konieczne jest maksymalne wykorzystanie wszystkich dostępnych zasobów, wymiana informacji i koordynacja działań. W działania, w ramach rehabilitacji audiologicznej, powinno być wpisane kształtowanie właściwych relacji i postaw wśród wszystkich osób zaangażowanych w ten proces. Relacje pomiędzy użytkownikiem implantu i jego najbliższym otoczeniem a przedstawicielami multidyscyplinarnego zespołu rehabilitacyjnego powinny odpowiadać zasadom opieki nastawionej na pacjenta (ang. Patient Oriented Care). Model ten, jak wynika z definicji opracowanej przez organizację The Institute of Medicine (IOM), zakłada, że terapeuta na każdym etapie rehabilitacji słuchu ściśle współpracuje z pacjentem (i jego rodziną) [88]. Co istotne, osoba implantowana posiada wiedzę z zakresu stosowania implantów ślimakowych i jest zaangażowana w cały proces terapeutyczny.

\section{Czynniki kontekstowe wewnętrzne}

Czynniki wewnętrzne wpływające na indywidualne możliwości przezwyciężania ograniczeń w aktywności i uczestnictwie po wszczepieniu implantu to czynniki osobowe takie jak: wiek, inne warunki zdrowotne, sprawność fizyczna, styl życia, nawyki, sposoby radzenia sobie z trudnościami, obecne doświadczenia, ogólne wzorce zachowań, style charakteru oraz cechy psychologiczne i inne cechy charakterystyczne, z których wszystkie lub każda oddzielnie mogą odegrać rolę w aktywności związanej z słuchaniem [1].

\section{Podsumowanie}

Wprowadzenie do praktyki klinicznej związanej ze stosowaniem implantów ślimakowych modelu rehabilitacji audiologicznej opracowanego na podstawie Międzynarodowej Klasyfikacji Zdrowia, Funkcjonowania i Niepełnosprawności (ICF) ma na celu ograniczenie negatywnych skutków niepełnosprawności słuchowej, dotyczących funkcji struktur i ciała ludzkiego, aktywności i uczestnictwa.

Klasyfikacja ICF to narzędzie kliniczne przydatne w ocenie potrzeb osób po wszczepieniu implantu ślimakowego. Wykorzystywane jest również do doboru metod postępowania w ramach rehabilitacji audiologicznej, będącej działaniem kompleksowym, złożonym $\mathrm{z}$ różnych form rehabilitacji medycznej, psychologicznej i społecznej, oraz w ocenie skuteczności tej rehabilitacji.

Dzięki klasyfikacji ICF możliwe było ujednolicenie języka stosowanego w opisie opieki zdrowotnej świadczonej po wszczepieniu implantu ślimakowego w celu usprawnienia porozumiewania się różnych specjalistów i pracowników służby zdrowia: lekarzy, logopedów, psychologów, pedagogów, inżynierów i pracowników naukowych.

Projekt został sfinansowany ze środków Narodowego Centrum Nauki przyznanych na podstawie decyzji numer DEC-2013/09/B/ ST7/04213.

\section{Piśmiennictwo:}

1. Światowa Organizacja Zdrowia. Międzynarodowa Klasyfikacja Funkcjonowania, Niepełnosprawności i Zdrowia (ICF). Warszawa: Centrum Systemów Informacyjnych Ochrony Zdrowia; 2009.

2. Skarżyński H, Lorens A, Piotrowska A. Wszczepy ślimakowe. W: Śliwińska-Kowalska M. Audiologia kliniczna. Łódź: Mediton, 2005; s. 429-42.

3. Karaś M. Niepełnosprawność, od spojrzenia medycznego do społecznego i Disability Studies. Law, Economical and Social Review (Przegląd Prawniczy, Ekonomiczny i Społeczny), 2012; 4: $20-33$.

4. Wiliński M. Modele niepełnosprawności: indywidualny - funkcjonalny - społeczny. W: Brzezińska A, Kaczan R, Smoczyńska K, red. Diagnoza potrzeb i modele pomocy dla osób z ograniczoną sprawnością. Warszawa; 2010, s. 15-60.

5. Piotrowska A, Lorens A, Szuchnik J, Wojewódzka B, Kosmalowa J, Skarżyński H. Procedura przedoperacyjna kwalifikacji do wszczepienia implantu ślimakowego stosowana w Instytucie Fizjologii i Patologii Słuchu w Warszawie. Audiofonologia; 2001, XX: 43-50.

6. Skarżyński H, Lorens A, Piotrowska A, Skarżyński PH. Hearing preservation in partial deafness treatment. Med Sci Monit, 2010; 16(11): 555-62.

7. Lorens A, Piotrowska A, Skarżyński H, Obrycka A. Zastosowanie elektronicznych protez wszczepialnych w leczeniu niedosłuchów. Pol Merkuriusz Lek. Sep, 2005; 19(111): 487-9.

8. Brandt E, Pope A. red. Enabling America: Assessing the role of rehabilitationscience and engineering. Washington, DC: National Academy; 1997.
9. Nagi SZ. Disability concepts revised: Implications for prevention. W: Pope A, Tarlov A, red. Disability in America: Toward a national agenda for prevention. Washington, DC: National Academy Press; 1991.

10. Audiology Australia WHO are we hear for? Models of Service Delivery. Position Paper; 2014.

11. British Society of Audiology. Common principles of rehabilitation for adults with hearing- and/or balance-related problems in routine audiology services. Practice Guidance; 2012.

12. WHO. International Classification of Functioning, Disability, and Health (ICF). Geneva, Switzerland: World Health Organization; 2001.

13. Heerkens Y, Hendriks E, Oostendorp R. Narzędzia oceny a Międzynarodowa Klasyfikacja Funkcjonowania w rehabilitacji i fizjoterapii. Rehabilitacja Medyczna, 2006; 10(3): 11-20.

14. Jagodziński R. Zastosowanie ICF jako narzędzia diagnozy, planowania i ewaluacji w programie aktywizacji społecznej i zawodowej osób niepełnosprawnych ruchowo. Niepełnosprawność - zagadnienia, problemy, rozwiązania, 2013; II(7): 67-103.

15. Wilmowska-Pietruszyńska A. Międzynarodowa Klasyfikacja Funkcjonowania, Niepełnosprawności i Zdrowia. Niepełnosprawność - zagadnienia, problemy, rozwiązania, 2013; II(7): 5-20.

16. Chen J. Functional capacity evaluation and disability. The Iowa Orthopaedic Journal, 2007; 27, 121-7.

17. Maini M, Nocentini U, Prevedini A, Giardini A, Muscolo E. An Italian experience in the ICF implementation in rehabilitation: Preliminary theoretical and practical considerations. Disability and Rehabilitation, 2008; 30(15): 1146-52. 
18. Bruyère $S$, VanLooy $S$, Peterson $D$. The International Classification of Functioning, Disability and Health (ICF): Contemporary literature overview. Rehabilitation Psychology, Educational Publishing Foundation, 2005; 50(2).

19. Danermark B, Cieza A, Gangé JP, Gimigliano F, Granberg S, Hickson L i wsp. International classification of functioning, disability, and health core sets for hearing loss: a discussion paper and invitation. Int J Audiol, 2010; 49(4): 256-62.

20. Danermark B, Granberg S, Kramer SE, Selb M, Möller C. The creation of a comprehensive and a brief core set for hearing loss using the International Classification of Functioning, Disability and Health. Am J Audiol, 2013; 22(2): 323-8.

21. Granberg S, Swanepoel DW, Englund U, Möller C, Danermark B. The ICF core sets for hearing loss project: International expert survey on functioning and disability of adults with hearing loss using the international classification of functioning, disability, and health (ICF). Int J Audiol, 2014; 53: 497-506.

22. Stephens D, Hétu R. Impairment, disability and handicap in audiology: towards a consensus. Audiology, 1991; 30: 185-200.

23. Chisolm TH, Johnson CE, Danhauer JL, Portz LJ, Abrams HB, Lesnerv $S$ i wsp. A systematic review of health-related quality of life and hearing aids: final report of the American Academy of Audiology Task Force On the Health-Related Quality of Life Benefits of Amplification in Adults. J Am Acad Audiol, 2007; 18: 151-83.

24. Sweetow R, Palmer CV. Efficacy of individual auditory training in adults: a systematic review of the evidence. J Am Acad Audiol, 2005; 16: 494-504.

25. Boothroyd A. Adult aural rehabilitation: what is it and does it work? Trends Amplif, 2007; 11(2): 63-71.

26. Dillon H. Hearing aids. Boomerang Press. Stuttgart: Thieme, 2001, Sydney.

27. Lorens A. Modelowanie słuchu elektrycznego. Praca doktorska. Gdańsk: Politechnika Gdańska, Katedra Inżynierii Dźwięku i Obrazu; 2002.

28. Shepherd RK, Hardie NA. Deafness-induced changes in the auditory pathway: implications for cochlear implants. Audiol Neurootol, 2001; 6(6): 305-18.

29. Sharma A, Gilley PM, Dorman MF, Baldwin R. Deprivation-induced cortical reorganization in children with cochlear implants. Int J Audiol, 2007; 46(9): 494-9.

30. Lorens A, Piotrowska A, Wąsowski A, Walkowiak A, Skarżyński $\mathrm{H}$. Objective method of peadiatric cochlear implant system fitting. New Medicine, 2004; 4(17): 109-11.

31. Wilson BS, Dorman MF. Cochlear implants: current designs and future possibilities.J Rehabil Res Dev, 2008; 45(5): 695-730.

32. Wilson BS, Dorman MF, Woldorff MG, Tucci DL. Cochlear implants matching the prosthesis to the brain and facilitating desired plastic changes in brain function. Prog Brain Res, 2011; 194: 117-29.

33. Lorens A, Obrycka A, Walkowiak A, Zgoda M, Putkiewicz A, Jeruzalska i wsp. Dopasowanie systemu implantu ślimakowego - Cookbook. Opracowanie własne Zakładu Implantów i Percepcji Słuchowej. Kajetany; 2014.

34. Lorens A, Skarżyński H, Piotrowska A, Walkowiak A, Śliwa L, Kochanek K. Objective methods of postoperative tests in cochlear implant patients. International Congress Series, 2003; 1240: $379-83$.

35. Furmanek M, Piotrowska A, Skarżyński H, Bogusławska-Walecka R, Walecki J. Value of multidetector computed tomography in detection of congenital inner ear malformations and its usefulness in qualification for cochlear implantation. Otolaryngol Pol, 2007; 61(4): 585-90.
36. Neuburger J, Lenarz T, Lesinski-Schiedat A, Büchner A. Spontaneous increases in impedance following cochlear implantation: suspected causes and management. Int J Audiol, 2009; 48(5): 233-9.

37. Walkowiak A, Lorens A, Polak M, Kostek B, Skarżyński H, Szkiełkowska A i wsp. Evoked stapedius reflex and compound action potential thresholds versus most comfortable loudness level: assessment of their relation for charge-based fitting strategies in implant users. J Otorhinolaryngol Relat Spec, 2011; 73(4): 189-95.

38. Longstaff A. Neurobiologia. Krótkie wykłady. Wydawnictwo Naukowe PWN; 2002.

39. Walkowiak A, Kostek B, Lorens A, Obrycka A, Wąsowski A, Skarżynski H. Spread of Excitation (SoE) - A non-invasive assessment of cochlear implant electrode placement. Cochlear Implants Int, 2010; 11(1): 479-81.

40. Walkowiak A, Lorens A, Kostek B, Skarżyński H. ESRT, ART and MCL correlations in experienced paediatric cochlear implant users. Cochlear Implants International, 2010; 11(1): $482-4$.

41. Lorens A, Walkowiak A, Piotrowska A, Skarżyński H, Anderson I. ESRT and MCL correlations in experienced paediatric cochlear implant users. Cochlear Implant Int, 2004; 5(1): 28-37.

42. Lorens A, Wąsowski A, Piotrowska A, Walkowiak A, Skarżyński $\mathrm{H}$. Zależność pomiędzy progiem elektrycznie wywołanego odruchu mięśnia strzemiączkowego a poziomem komfortowego słyszenia MCL zmierzonego w oparciu o wybrane metody psychoakustyczne. Audiofonologia, 2006; XXVIII: 55-9.

43. Jeon JH, Bae MR, Song MH, Noh SH, Choi KH, Choi JY. Relationship between electrically evoked auditory brainstem response and auditory performance after cochlear implant in patients with auditory neuropathy spectrum disorder. Otol Neurotol, 2013; 34(7): 1261-6.

44. Beynon AJ, Snik AF, van den Broek P. Evaluation of cochlear implant benefit with auditory cortical evoked potentials. Int J Audiol, 2002; 41(7): 429-35.

45. Skarżyński H, Lorens A, Piotrowska A. A new method of partial deafness treatment. Med Sci Monit, 2003; 9(4): 20-4.

46. Steel MM, Abbasalipour P, Salloum CA, Hasek D, Papsin BC, Gordon KA. Unilateral cochlear implant use promotes normal-like loudness perception in adolescents with childhood deafness. Ear Hear, 2014; 35(6): 291-301.

47. Vaerenberg B, Smits C, De Ceulaer G, Zir E, Harman S, Jaspers $\mathrm{N}$ i wsp. Cochlear implant programming: A global survey on the state of the art. Scientific World Journal, 2014; 2014: 501738 .

48. Kricos PB, McCarthy P. From ear to there: A historical perspective on auditory training. Semin Hear, 2007; 28(2): 89-98.

49. Munro KJ, Merrett JF. Brainstem plasticity and modified loudness following short-term use of hearing aids. J Acoust Soc Am, 2013; 133(1): 343-9.

50. Moore BCJ. Wprowadzenie do psychologii słyszenia. Państwowe Wydawnictwa Naukowe; 1999.

51. Ozimek E. Dźwięk i jego percepcja. Aspekty fizyczne i psychoakustyczne. Wydawnictwo PWN; 2002.

52. Lorens A, Skarżyński H, Piotrowska A. New methods of deafness and partial deafness treatment. Biocybernetics and Biomedical Engineering, 2006; 26: 75-83.

53. Walkowiak A. Symulacja słyszenia pacjenta $\mathrm{z}$ implantem ślimakowym. Praca doktorska. Gdańsk: Politechnika Gdańska, Wydział Elektroniki, Telekomunikacji i Informatyki; 2013. 
54. Lorens A, Zgoda M, Obrycka A, Skarżyński H. Fine Structure Processing improves speech perception as well as objective and subjective benefits in pediatric MED-EL COMBI 40+ users. Int J Pediatr Otorhinolaryngol, 2010; 74(12): 1372-8.

55. Chen JK, Chuang AY, McMahon C, Hsieh JC, Tung TH, Li LP. Music training improves pitch perception in prelingually deafened children with cochlear implants. Pediatrics, 2010; 125(4): 793-800.

56. Blamey PJ, Maat B, Başkent D, Mawman D, Burke E, Dillier N i wsp. Retrospective multicenter study comparing speech perception outcomes for bilateral implantation and bimodal rehabilitation. Ear Hear, 2015; 18; w druku.

57. van Zon A, Peters JP, Stegeman I, Smit AL, Grolman W. Cochlear implantation for patients with single-sided deafness or asymmetrical hearing loss: a systematic review of the evidence. Otol Neurotol, 2015; 36(2): 209-19.

58. Kahneman D. Attention and effort: Measurement. Englewood Cliffs, NJ: Prentice-Hall; 1973.

59. Kramer SE, Lorens A, Coninx F, Zekveld AA, Piotrowska A, Skarżyński H. Processing load during listening: The influence of task characteristics on the pupil response. Language And Cognitive Processes, 2013; 28(4): 426-42.

60. Kowalczyk A. Preferencje dźwięków w krajobrazie. W: Dźwięk w krajobrazie jako przedmiot badań interdyscyplinarnych. Instytut Nauk o Ziemi UMCS, Prace Komisji Krajobrazu Kulturowego PTG, 2008; 11: 36-43.

61. Lerch M, Decker-Maruska M. The importance of hearing for older adults: A geriatrician's perspective. Journal of Hearing Science, 2012; 2(4): 40-2.

62. Tyler R, Kelsay D. Advantages and disadvatages reported by some of the better cochlear implant patiens. Am J Otol, 1990; 11(4): 282-9.

63. Pals C, Sarampalis A, Baskent D. Listening effort with cochlear implant simulations. J Speech Lang Hear Res, 2013; 56(4): 1075-84.

64. Winn MB, Edwards JR, Litovsky RY. The impact of auditory spectral resolution on listening effort revealed by pupil dilation. Ear Hear, 2015; w druku.

65. Skarżyński H, Lorens A, Matusiak M, Porowski M, Skarżyński PH, James CJ. Partial deafness treatment with the nucleus straight research array cochlear implant. Audiol Neurootol, 2012; 17(2): 82-91.

66. Hughes KC, Galvin KL. Measuring listening effort expended by adolescents and young adults with unilateral or bilateral cochlear implants or normal hearing. Cochlear Implants Int, 2013; 14(3): 121-9.

67. Francis A, Nusbaum H. Effects of intelligibility on working memory demand for speech perception. Atten Percept Psychophys, 2009; 71(6): 1360-74.

68. Solnica J, Kobosko J, Pankowska A, Zgoda M, Skarżyński H. Efektywność treningu słuchowego osób z częściową głuchotą po wszczepieniu implantu ślimakowego $\mathrm{w}$ ocenie pacjentów i logopedów. Nowa Audiofonologia, 2012; 1(1): 31-7.

69. Cox RM, Alexander GC. The abbreviated profile of hearing aid benefit. Ear Hear, 1995; 16(2): 176-86.

70. Obrycka A, García JL, Pankowska A, Lorens A, Skarżyński H. Production and evaluation of a Polish version of the LittlEars questionnaire for the assessment of auditory development in infants. Int J Pediatr Otorhinolaryngol, 2009; 73(7): 1035-42.
71. Skarżyński H, Lorens A, Piotrowska A, Podskarbi-Fayette R. Results of partial deafness cochlear implantation using various electrode designs. Audiol Neurootol, 2009; 14 Suppl. 1: 39-45.

72. Wąsowski A, Lorens A, Obrycka A, Walkowiak A, Woźniak A, Skarżyński H i wsp. Influence of non-optimal levels of electrical stimulation in cochlear implantees on hearing benefits. Cochlear Implants Int, 2010; 11(1): 485-8.

73. Fu QJ, Galvin JJ 3rd. Maximizing cochlear implant patients' performance with advanced speech training procedures. Hear Res, 2008; 242(1-2): 198-208.

74. Lorens A, Obrycka A, Piotrowska A. Walidacja list artykulacyjnych wg Pruszewicza dla oceny zrozumiałości mowy w szumie. Audiofonologia, 2006; XXVIII: 71-7.

75. Coninx F, Lorens A, Piotrowska A, Hubinger P, Skarżyński H. The Adaptive Auditory Speech Test (AAST) - development of the Polish version. Materiały zjazdowe $11^{\text {th }}$ International Conference on Cochlear Implants in Children. Charlotte, USA; 2007.

76. Arlinger S, Lunner T, Lyxell B, Pichora-Fuller MK. The emergence of cognitive hearing science. Scand J Psychol, 200; 50(5): 371-84.

77. Rönnberg, J, Rudner, M, Foo, C, Lunner, T. Cognition counts: A working memory system for ease of language understanding (ELU). International Journal of Audiology, 2008; 47: 171-7.

78. Huitt W. The information processing approach to cognition. Educational Psychology Interactive. Valdosta, GA: Valdosta State University; 2003.

79. Clark J, Martin F. Effective counseling in audiology: Perspectives and practice. Englewood Cliffs: Prentice Hall; 1994.

80. Tye-Murray N. Communication strategies Training. Journal of the Academy of Rehabilitative Audiology, 1994; 27 (Monograph Supplement): 193-207.

81. Mahncke HW, Connor BB, Appelman J, Ahsanuddin ON, Hardy JL, Wood RA i wsp. Memory enhancement in healthy older adults using a brain plasticity-based training program: a randomized, controlled study. Proc Natl Acad Sci USA, 2006; 103(33): 12523-8.

82. Kronenberger WG, Pisoni DB, Henning SC, Colson BG, Hazzard LM. Working memory training for children with cochlear implants: a pilot study. J Speech Lang Hear Res, 2011; 54(4): 1182-96.

83. Daneman M, Carpenter PA. Individual differences in working memory and reading. Journal of Verbal Learning and Verbal Behaviour, 1980; 19: 450-66.

84. Stachowska M. Rehabilitacja psychologiczna. W: Milanowska K, Dega W, red. Rehabilitacja medyczna. Warszawa: Wydawnictwo Lekarskie PZWL; 1998, 124.

85. Kamusińska E. Znaczenie kompleksowej rehabilitacji w integracji osób niepełnosprawnych ze społeczeństwem. Studia Medyczne, 2008; 9: 83-6.

86. Jagodziński R. Zastosowanie ICF jako narzędzia diagnozy, planowania i ewaluacji w programie aktywizacji społecznej i zawodowej osób niepełnosprawnych ruchowo. Niepełnosprawność - Zagadnienia, Problemy, Rozwiązania, 2013; 2(7): 67-104.

87. Sackett D, Rosenberg W, Gray J, Haynes R, Richardson W. Evidence-Based Medicine: What it is and what it isn't. BMJ, 1996; 312: 71-2.

88. IOM 2001. Crossing the Quality Chasm: A New Health System for the $21^{\text {st }}$ Century. 